\title{
The Evolution Of Disability Among Surveys In Spain
}

Leticia Meseguer-Santamaría, University of Castilla-La Mancha, Spain Manuel Vargas-Vargas, Ph.D., University of Castilla-La Mancha, Spain José Mondéjar Jiménez, Ph.D., University of Castilla-La Mancha, Spain

\begin{abstract}
The definition of the word disability is controversial, due to his complexity and multidimensionality. The successive disability models and their empirical measurement in the diverse health national surveys vary greatly. The International Classification of Functioning, Disability, and Health (World Health Organization, 2001), known as the ICF, sees disability as the outcome of interactions between the features of the individual and the physical, social, and attitudinal world. This approach has the dual advantage of stressing the social context in which individuals are enabled or excluded while not ruling out the roles of bodies and medicine. In this paper, we analyze the evolution of the measurement of disability among three health national surveys in Spain.
\end{abstract}

Keywords: Disability, Dependence, Classification, National Surveys

\section{INTRODUCTION}

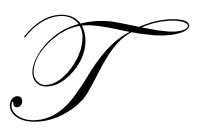

his paper presents a comparative analysis of three surveys of disability in Spain. We study the evolution of the terms, their different meanings or how they have incorporated other, adapting to prevailing social demands. It attempts to give an overview of disability in Spain, assuming they are surveys with different designs, as shown Portal Mayores (2009). Other comparative analysis can be found in the works Jimenez and Huete (2003), Abellán and Puja (2004) and the developed by the National Institute of Statistics (INE) in its Report on the Survey on Disabilities, Impairments and Health Status (2002).

In the past 25 years, statistical information on disability in Spain has provided a great change, culminating with the appearance of specific surveys, developed by the INE in collaboration with different organizations. The aim is to meet the new demand for quantitative data for analysis of the disability, the persons concerned, and society in general.

This evolution is part of an overall change in the conception of persons with disabilities. Both at the policy, legislative and social level, is fundamental the proactive role of these people, because they have the right and duty to participate actively in a society for everyone.

Thus, in this context, the Survey on Disabilities, Impairments and Handicaps (Encuesta sobre Discapacidades, Deficiencias y Minusvalías, EDDM-1986), Survey on Disabilities, Impairments and Health Status (Encuesta sobre Discapacidad, Deficiencia y Estado de Salud, EDDES-1999), and Survey on Disability, Personal Autonomy and Dependency Situations (Encuesta sobre Discapacidad, Autonomía personal y Situaciones de Dependencia, EDAD-2008), are very important tools to study the situation and needs of people with disabilities. 


\section{SURVEYS}

\section{Survey on Disabilities, Impairments and Handicaps (EDDM-1986).}

Based on the International Classification of Impairments, Disabilities and Handicaps (ICIDH) developed by the World Health Organization (WHO) in 1980, the INE, in collaboration with the INSERSO, developed in 1986 the first specific survey on disability in Spain: the Survey on Disabilities, Impairments and Handicaps (EDDM-1986). Whit it, the INE estimated the number of people with disabilities in Spain, including variables on the subject of the survey as gender or age, and others on the economic livelihood of the family, such as educational level, economic activity, etc.

It is the first step in a more specific analysis of this group, but it still lacks important elements, which are incorporated successively over time, as the involvement of this collective in developing the survey itself, or the inclusion of many more social aspects: use of health services, leisure, suffered discrimination or abuse, etc.

The above classification distinguishes between impairment, disability and handicap. The first definition refers to the individual permanent limitations due to loss or abnormalities of the organizational structure (physiological, psychological or anatomical); is an organic level. Disabilities refer to the restrictions or inability to perform certain daily activities considered normal; is an individual level. And finally, the handicaps relate to the disadvantages arising as a consequence of having an impairment or a disability and how to adapt the individual to his environment; reaching therefore a social dimension. The following table shows the distribution of the observable manifestations in practice:

Table 1: Distribution of the observable manifestations of impairments, disabilities and handicaps

\begin{tabular}{|c|c|c|c|}
\hline Level & Impairments & Disabilities & Handicaps \\
\hline Contents & $\begin{array}{l}\text { Intellectual impairments. } \\
\text { Other psychological deficiencies. } \\
\text { Shortcomings of language. } \\
\text { Weaknesses of the organ of hearing. } \\
\text { Deficiencies of the organ of vision. } \\
\text { Weaknesses visceral. } \\
\text { Muscle-skeletal deficiencies. } \\
\text { Weaknesses disfigured. } \\
\text { Widespread deficiencies, sensitive and } \\
\text { others. }\end{array}$ & $\begin{array}{l}\text { Behavioral disabilities. } \\
\text { Communication disabilities. } \\
\text { Personal care disabilities. } \\
\text { Locomotion disabilities. } \\
\text { Disabilities of the disposition of the } \\
\text { body. } \\
\text { Disabilities skill. } \\
\text { Situational disabilities. } \\
\text { Disabilities of a particular skill. }\end{array}$ & $\begin{array}{l}\text { Guidance handicap. } \\
\text { Physical independence } \\
\text { handicap. } \\
\text { Mobility handicap. } \\
\text { Occupational handicap. } \\
\text { Handicap of social integration. } \\
\text { Economic self-sufficiency } \\
\text { handicap. } \\
\text { Other handicaps. }\end{array}$ \\
\hline
\end{tabular}

The main limitations of the ICIDH model are its excessive individualistic and one-dimensional approach, the low involvement of society and the environment, as well as it predominantly negative character based on deficiencies.

\section{Survey on Disabilities, Impairments and Health Status (EDDES-1999)}

The ICIDH has been and is under continuous review at international level. Today, it remains a living definition, which attempts to adapt to the society but keeping a few pillars in their definitions for the comparability of different points in time and the study of the evolution of disability. Excellent discussion and analysis can be found in the works of Egea and Sarabia (2001) and Jiménez, Gonzalez and Martin (2002).

In 1999, the INE, the Institute of Migration and Social Services (Instituto de Migraciones y Servicios Sociales, IMSERSO) and the Foundation of the National Organization of Blind from Spain (Organización Nacional de Ciegos de España, ONCE), developed the Survey of Disability, Impairment and Health Status (EDDES-1999). Here, disability is defined as "any restriction or significant distress, due to a deficiency, on a person to perform daily activities such as mobility, take care of yourself, see, hear, interact with others, etc.". People with disabilities were defined by asking directly if they had a particular disability. This new survey seeks to respond to a society more aware of the importance of this collective, being aware of its importance in a pluralistic community. 
The information is gathered primarily from the perspective of the person and not just the deficiency, introducing aspects as the need to assist in carrying out daily activities, or relative caregivers of persons with disabilities, the use of social and health services. The survey includes a health module that was on different aspects (such as self-assessment of the state health, time constraints of daily activities, accidents in the home, entertainment, prevalence of chronic diseases, lifestyle habits, and economic, educational and work) aimed to improve the integration of people with disabilities in education and the workplace. A deeper study can be found in Jiménez and Huete (2003).

\section{Survey on Disability, Personal Autonomy and Dependency Situations (EDAD-2008).}

As discussed above, the ICIDH has undergone major changes throughout its history. Thus, in 2001, the WHO published the International Classification of Functioning, Disability and Health (ICF). As recorded in the report on methodology of the Survey on Disability, Personal Autonomy and Dependency Situations (2008), disability means "the term for impairments, disabilities (now limitations on activity) and handicap (now participation restrictions), and introduce another crucial difference from the previous ICIDH: ICF expands the concept of health to incorporate environmental factors (physical environment, social and attitudinal in which people live and conduct their lives.)

The part of the ICF about functioning and disability has two components:

- $\quad$ Functions of body systems and body structures. Bodily functions are the physiological functions of body systems. The body structures are anatomical parts of it. The deficiencies are problems in these functions or structures.

- Activities and participation. Activity is the execution of a task by an individual. Participation is the act of engaging in a life situation. Activity limitation is the difficulty at individual-level in the performance / conduct of an activity. Restriction on participation is the difficulty you may have a person involved in a situation from a social perspective."

Society is changing, and it should be for everyone, with the participation of all people. It requires the adaptation of society itself to facilitating and encouraging the active participation of its members. It develops plans and programs that integrate people with disabilities in social, cultural, health, economic, entertainment, politics, business, etc.; and, generally, in all areas of life and all levels of decision. It promotes measures about accessibility, prevention of discrimination, access to decision positions, education, jobs, economic aid, leisure activities, etc. They also change gender stereotypes and roles assigned to each one, driven by changes in society, as the full incorporation of women to work (female employment rates in the fourth quarter of 2009 in Spain were $53.27 \%$ and $66.34 \%$ for men), or the different family models that appear and increase its relative importance over other more traditional.

Thus, in 2008, a working group is established to develop the Survey of Disability, Personal Autonomy and Dependency Situations (EDAD-08). It comprises the INE, IMSERSO, the Directorate General for Coordination of Sectoral Policies on Disability, the ONCE Foundation, the Spanish Committee of Representatives of People with Disabilities (CERMI) and the Spanish Confederation of Organizations for People with Intellectual Disability (FEAPS).

The EDAD-2008 expands its field of action to study the population living in households and in collective centers, which in its preparation are two stages, the first directed to households (EDAD-hogares), and the second one aimed at mental hospitals and nursing homes, senior centers, or fewer than 65 with disabilities, etc. In the EDAD-hogares, persons are asked if they have limitations to the performance of daily activities, unlike what was done in the EDDES, by directly asking about disabilities. This modification is intended to measure the difficulties that may occur on participation and social activity. As for the structure of disabilities, there are no major differences, extending disability groups from 36 to 44 . The following table establishes the correspondence between EDDES and EDAD: 
Table 2: Correspondence between EDDES, EDAD and ICF

\begin{tabular}{|l|l|l|}
\hline \multicolumn{1}{|c|}{ EDAD-2008 } & \multicolumn{1}{|c|}{\begin{tabular}{c}
\multicolumn{1}{c|}{ Chapter ICF } \\
(Activities and Participation)
\end{tabular}} & \multicolumn{1}{c|}{ EDDES-1999 } \\
\hline 1. Vision & Body Functions (visual functions) & 1. Vision \\
\hline 2. Hearing & Body Functions (hearing functions) & 2. Hearing \\
\hline 3. Communication & 3. Communication & 3. Communicate \\
\hline $\begin{array}{l}\text { 4. Learn, apply knowledge, and } \\
\text { perform task }\end{array}$ & $\begin{array}{l}\text { Part of Chapters } \\
\text { 1. Learning and application of knowledge } \\
\text { 2. Tasks and general demands }\end{array}$ & $\begin{array}{l}\text { 4. Learn, apply knowledge, and } \\
\text { perform tasks (only mental functions) }\end{array}$ \\
\hline 5. Mobility & 4. Mobility & $\begin{array}{l}\text { 5. Move } \\
\text { 6. Using hand and arms } \\
\text { 7. Moving away from home }\end{array}$ \\
\hline 6. Self care & 5. Self Care & 8. Self care \\
\hline 7. Household Life & 6. Household Life & 9. Household chores \\
\hline $\begin{array}{l}\text { 8. Interactions and interpersonal } \\
\text { relationships }\end{array}$ & 7. Interactions and interpersonal relationships & 10. Interacting with other people \\
\hline
\end{tabular}

Source: INE. Report on Methodology of the Survey on Disability, Personal Autonomy and Dependency Situations. Madrid, 2009

\section{COMPARATIVE ANALYSIS}

Being aware of the differences described in previous paragraphs, the next table shows the numbers of people with disabilities in Spanish society. Fixing our attention on the last two surveys, which are closer to the definition of disability, we see that the weight of the disabled population to the total decreases in both, the female and the male.

Table 3: People with disabilities from the EDDM-1986, EDDES-1999 y EDAD-2008

\begin{tabular}{|c|c|c|c|c|c|c|}
\hline \multirow{2}{*}{ Survey } & \multicolumn{2}{|c|}{ Total } & \multicolumn{2}{|c|}{ Female } & \multicolumn{2}{|c|}{ Male } \\
\hline & People & Prevalence & People & Prevalence & People & Prevalence \\
\hline EDDM-1986 & $5,743,291$ & $15.00 \%$ & $3,245,370$ & $16,50 \%$ & $2,497,921$ & $13.30 \%$ \\
\hline EDDES-1999 & $3,528,221$ & $9.00 \%$ & $2,055,251$ & $10.30 \%$ & $1,472,971$ & $7.70 \%$ \\
\hline EDAD-2008 & $3,847,900$ & $8.55 \%$ & $2,300,200$ & $10.10 \%$ & $1,547,700$ & $6.95 \%$ \\
\hline
\end{tabular}

Source: INE. Madrid, 2009

When analyzing the prevalence of disability by gender, we must note that in all three surveys, women are above men by about three percentage points. Therefore, women are more than half of people with disabilities, exactly $59.78 \%$ in the EDAD-2008, a figure that has increased over time $56.51 \%$ in the EDDM-86, and 58.25\% in the EDDES-1999). In total, the rate of people with disabilities is $8.55 \%$ and, in the female sector, reached $10.10 \%$.

Regarding the influence of age on disability, the next figures detail their prevalence in the three years analyzed. In the last two surveys, we see that is at age 70 when there is sudden change of slope: before that age, the prevalence does not reach the $20 \%$ and from it, it shoots up to $70 \%$ or more. In women, this inflection occurs earlier, around age 65 .

Figure 1: Disability prevalence by gender and age from EDDM-1986, EDDES-1999, and EDAD-2008
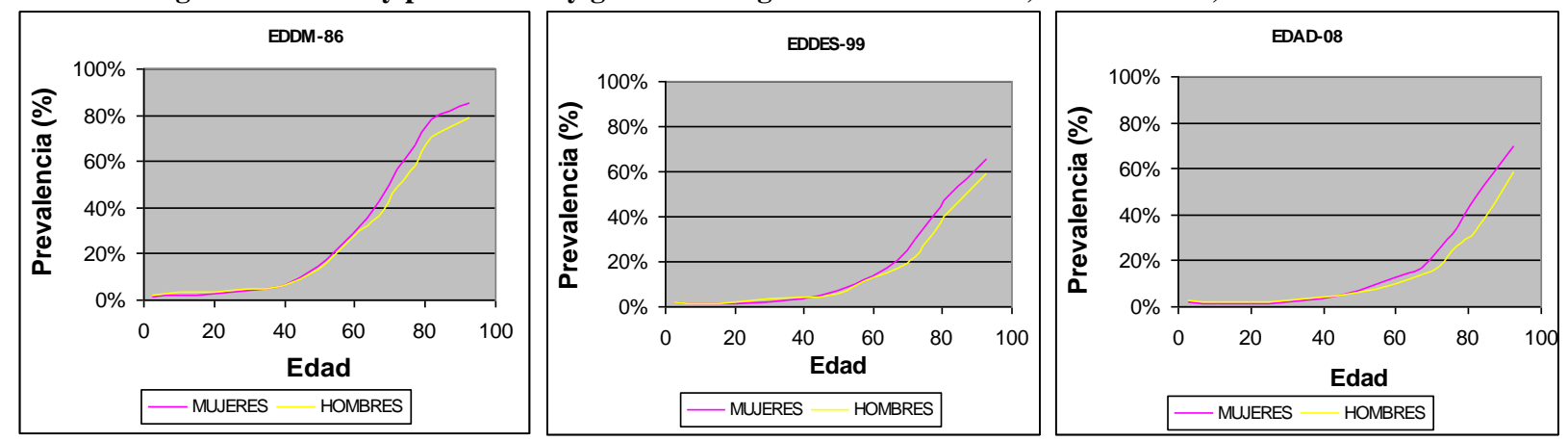

Sources: INE. Madrid, 2009 
The analysis of this sequence shows that, in general, to 50 years the prevalence of disability is slightly higher among men, and from this age, it is women who have the highest rates, widening the gap with increasing age. It should also be noted that over time, comparing the surveys for the years 1999 and 2008, this difference from the age of 50 is increasing.

Finally, there are important differences between the EDDES-1999 and EDAD-2008 in the disability groups. Following the adjustment provided by the INE, explained above, we can draw the following table and graphs.

Table 4: Disability Groups. Comparative between EDDES-1999 and EDAD-2008

\begin{tabular}{|c|c|c|c|c|c|c|c|}
\hline \multirow{2}{*}{ Disability Groups EDDES } & \multicolumn{2}{|c|}{ Total } & \multicolumn{2}{|c|}{ Female } & \multicolumn{2}{|c|}{ Male } & \multirow{2}{*}{$\begin{array}{l}\text { Disability Groups } \\
\text { EDAD }\end{array}$} \\
\hline & EDDES & EDAD & EDDES & EDAD & EDDES & EDAD & \\
\hline 1. Vision & 1.002 .291 & 979.000 & 600.693 & 607.700 & 401.598 & 371.300 & 1. Vision \\
\hline 2. Hearing & 961.348 & 1.064 .100 & 540.666 & 608.500 & 420.682 & 455.700 & 2. Hearing \\
\hline 3. Communicate & 359.356 & 734.200 & 179.471 & 397.500 & 179.885 & 336.600 & 3. Communicate \\
\hline $\begin{array}{l}\text { 4. Learn, apply knowledge and } \\
\text { perform tasks (only mental } \\
\text { functions) }\end{array}$ & 574.410 & 630.000 & 336.894 & 365.500 & 237.516 & 264.500 & $\begin{array}{l}\text { 4. Learn, apply } \\
\text { knowledge, and } \\
\text { perform task }\end{array}$ \\
\hline Subtotal Mobility (5, 6 and 7) & 4.406 .587 & \multirow{4}{*}{2.535 .400} & 2.763 .188 & \multirow{4}{*}{1.653 .900} & 1.643 .399 & \multirow{4}{*}{881.500} & \multirow{4}{*}{ 5. Mobility } \\
\hline 5. Move & 1.224 .032 & & 789.717 & & 434.315 & & \\
\hline 6. Using hand and arms & 1.092 .872 & & 682.765 & & 410.107 & & \\
\hline 7. Moving away from home & 2.089 .683 & & 1.290 .706 & & 798.977 & & \\
\hline 8. Self care & 776.878 & 1.824 .500 & 473.028 & 1.179 .500 & 303.850 & 645.000 & 6. Self care \\
\hline 9. Household chores & 1.460 .574 & 2.079 .200 & 1.024 .185 & 1.473 .400 & 436.389 & 605.800 & 7. Household chores \\
\hline $\begin{array}{l}\text { 10. Interacting with other } \\
\text { people }\end{array}$ & 568.716 & 621.200 & 330.374 & 329.500 & 238.342 & 291.700 & $\begin{array}{l}\text { 8. Interactions and } \\
\text { interpersonal } \\
\text { relationships }\end{array}$ \\
\hline Total & 3.478 .644 & 3.787 .400 & 2.030 .396 & 2.276 .500 & 1.448 .248 & 1.510 .900 & Total \\
\hline
\end{tabular}

Source: INE. Madrid, 2009

Figures 2 and 3: Disability Groups. Comparative between EDDES-1999 and EDAD-2008. Female and Male.
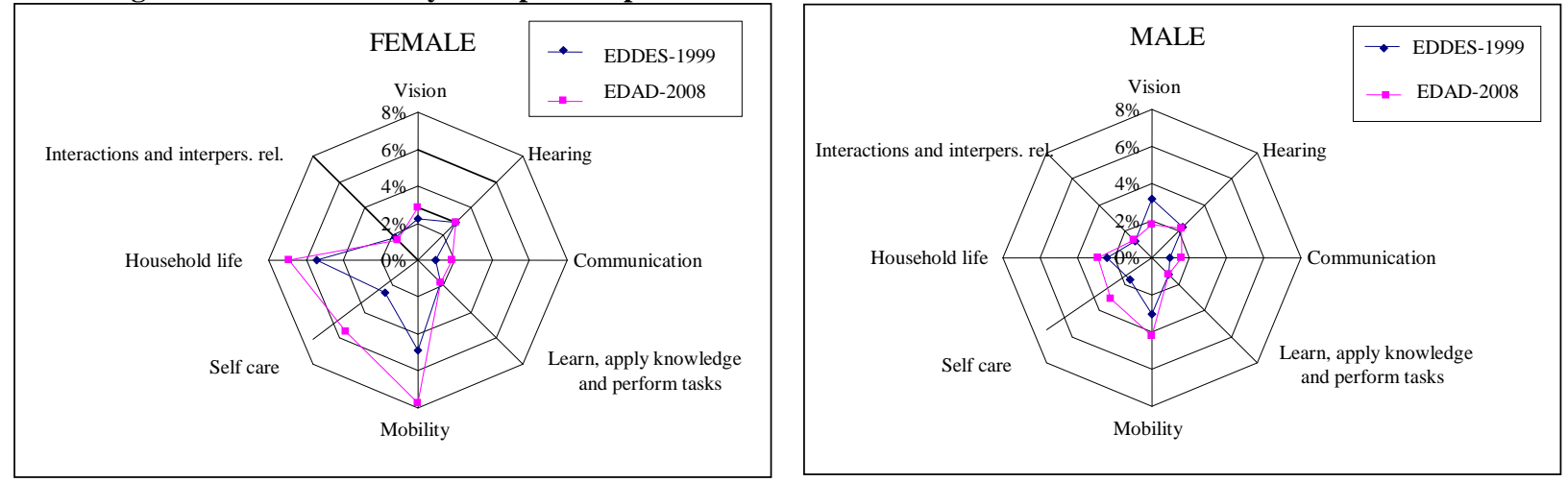

Source: INE. Madrid, 2009

We note that women are significantly more difficulties in mobility and for daily activities, and that in general, except in the group related to the vision, have higher percentages. Both differences are exacerbated among the EDDES-1999 and EDAD-2008.

\section{CONCLUSIONS}

- In recent decades, people with disabilities have increased its number in absolute terms, but has declined your rate over the total population. According to the EDAD-2008, in Spain people with disabilities are more than 3.8 million (8.55\% of total population), compared to 3,528,221 in the EDDES-1999 (9\% the total population). 
- $\quad$ They are more women than men with disabilities. Nearly $60 \%$ of the people with disabilities are women according to EDAD-2008, a percentage that has increased in recent decades $(56.51 \%$ in the EDDM-1986 and $58.25 \%$ in the EDDES-1999).

- As age increases, the proportion of people with disabilities increases, resulting in an important turning around 67 years, and until that age the prevalence of disability does not reach 20 percent, and from it rises to more than $70 \%$. The data from EDDES-1999 and EDAD-2008 support this finding.

- $\quad$ Until age 50, men show a higher prevalence of disability; then, women are the highest values. Comparing EDDES-1999 and EDAD-2008, we see that this pattern is repeated, but the differences between men and women aged 50 have increased in this decade.

- In general, women have a higher prevalence on every disability group, except in vision.

- The structure of disabilities by group remains the same between EDDES-1999 to EDAD-2008, increasing the differences by gender.

\section{AUTHOR INFORMATION}

María-Leticia Meseguer-Santamaría: MBA in Economics Degree in Business Administration by University of Castilla-La Mancha. Assistant Professor in Statistics at Statistics Department. Faculty of Economics and Business Administration of Albacete. University of Castilla-La Mancha (Spain). E-mail: MLeticia.Meseguer@uclm.es.

Research Interest: disability, women studies, educational and tourism.

Manuel Vargas-Vargas: PhD in Economics by University of Castilla-La Mancha and Degree in Mathematics by University of Granada. Associate Professor in Statistics at Statistics Department. Faculty of Economics and Business Administration of Albacete, University of Castilla-La Mancha (Spain). E-mail: Manuel.Vargas@uclm.es. Research Interest: disability, regional analysis, educational and tourism.

José Mondéjar-Jiménez: European PhD in Economics and Degree in Business Administration by University of Castilla-La Mancha. Associate Professor at Statistics Department. Faculty of Social Sciences of Cuenca. University of Castilla-La Mancha (Spain). E-mail: Jose.Mondejar@uclm.es.

Research Interest: disability, regional analysis, educational and tourism.

\section{REFERENCES}

1. Abellán, A. (2000). Nuevo modelo de funcionamiento y la discapacidad. Revista Multidisciplinar de gerontología, 10(3), 189-192.

2. Abellán, A. and Puja, M. D. (2004). Una estimación de la dependencian. Revista Multidisciplinar de gerontología, 14(5), 301-303.

3. Altman, B. M. (2001). Disability Definitions, Models, Classification Schemes, and Applications. In G. L. Albrecht, K. D. Seelman, and M. Bury (eds.) Handbook of Disability Studies. Thousand Oaks, CA: Sage.

4. Bayot, A. (2006). Estudio cualitativo de la situación de la mujer con discapacidad en Castilla-La Mancha. Toledo: COCEMFE.

5. Comisión de las Comunidades Europeas (2003). Igualdad de oportunidades para las personas con discapacidad: un plan de acción europea. 2004-2010. Bruselas. <http://europa.eu/legislation_summaries/employment_and_social_policy/disability_and_old_age/c11414_e s.htm>.

6. $\quad$ Consejo de Europa. Comité de Ministros (2006). Plan de acción del Consejo de Europa para la promoción de los derechos y de la plena participación de las personas discapacitadas en la sociedad: mejorar la calidad de vida de las personas discapacitadas en Europa 2006-2015. Bruselas. <http://www.infodisclm.com/legislacion\%20europea.htm\#seis $>$.

7. Egea, C. \& Sarabia, A. (Grupo A \& C Consultores) (2001) Experiencias de Aplicación en España de La Clasificación Internacional de Deficiencias Discapacidades y Minusvalías. Madrid: Real Patronato sobre Discapacidad. Doc 58/2001.

8. Instituto Nacional de Estadística (1987). Encuesta sobre Discapacidades, Deficiencias y Minusvalías de1986. Madrid. 
9. Instituto Nacional de Estadística (2002). Encuesta sobre Discapacidades, Deficiencias y Estado de Salud de1999. Resultados detallados. Madrid.

10. Instituto Nacional de Estadística (2009). Encuesta sobre Discapacidad, Autonomía Personal y Situaciones de Dependencia de 2008. Metodología. Madrid.

11. Instituto Nacional de Servicios Sociales (1983). Clasificación Internacional de Deficiencias, Discapacidades y Minusvalías. Manual de clasificación de las consecuencias de la enfermedad. Madrid.

12. Jiménez, A. y Huete, A. (2003). La discapacidad en España: Datos estadísticos. Aproximación desde la Encuesta sobre Discapacidades, Deficiencias y Estado de Salud de 1999, Doc. 62/2003. Madrid: Real Patronato sobre Discapacidad.

13. Jiménez, M. T.; González, P. \& Martín, J. M. (2002). La clasificación internacional del funcionamiento de la discapacidad y de la salud (CIF) 2001. Revista Española de Salud Pública, 76(4), 271-279.

14. Junta de Andalucía (2008). I Plan de Acción Integral para Mujeres con Discapacidad de Andalucía, 2008 2013. Sevilla: Consejería de Igualdad y Bienestar Social.

15. Malo, M. A. (2007): La definición de la discapacidad en la investigación económica: Una reflexión necesaria sobre qué características debería cumplir. Revista Estudios de Economía Aplicada, 25(2), 407428.

16. Ministerio de Trabajo y Asuntos Sociales (2003). II Plan de Acción para las personas con discapacidad 2003-2007. Madrid: Secretaría General de Asuntos Sociales, Instituto de Migraciones y Servicios Sociales.

17. Ministerio de Trabajo y Asuntos Sociales (2006). Plan de Acción para las mujeres con discapacidad 2007. Madrid: Secretaría General de Asuntos Sociales, Familias y Discapacidad. Secretaría General de Coordinación de políticas sectoriales sobre la discapacidad.

18. Ministerio de Sanidad y Política Social (2009). III Plan de Acción para las personas con discapacidad 20093-2012. Madrid: Dirección General de Coordinación de Políticas Sectoriales sobre la Discapacidad del Ministerio de Sanidad y Política Social

19. World Health Organization (2001). Clasificación Internacional del Funcionamiento, de la Discapacidad y de la Salud: CIF. Madrid: Instituto de Migraciones y Asuntos Sociales (IMSERSO). <http://www.ilo.org/public/spanish/employment/skills/disability/draftcod.htm>.

20. Palacios, A. (2008). El modelo social de la discapacidad: orígenes, caracterización y plasmación en la convención internacional sobre los derechos de las personas con discapacidad. Madrid: Comité Español de Representantes de Personas con Discapacidad (CERMI). Colection CERMI.es, 36.

21. Pascual, M. \& Cantarero, D. (2007). Características Socio-económicas de las Personas con Discapacidad en España: Un análisis Empírico. Revista Estudios de Economía Aplicada, 25(3), 843-866.

22. Portal Mayores (2009). La discapacidad en Europa. Madrid: Informes Portal Mayores, nº 93. [29/09/2009, version 3]. <http://www.imsersomayores.csic.es/documentos/documentos/pm-disca-en-europa-200603.pdf>. 
NOTES 